\title{
BETWEEN THE COLD WAR AND THE GLOBAL SOUTH: ARGENTINA AND THIRD WORLD SOLIDARITY IN THE FALKLANDS/MALVINAS CRISIS
}

Entre a Guerra Fria e o Sul Global: a Argentina e a solidariedade do Terceiro Mundo na crise das Malvinas

Entre la Guerra Fría y el Sur Global: la Argentina y la solidaridad del Tercer Mundo en la Crisis de las Malvinas

STELLA PARESA KREPP

http://dx.doi.org/10.1590/\$2178-14942017000100008

Stella Paresa Krepp é PhD em História pela Universidade de Cambridge (Reino Unido) e professora assistente de História Ibérica e Latino-Americana da Universidade de Berna (Suiça) (stella.krepp@hist.unibe.ch).

Artigo recebido em 13 de dezembro de 2016 e aprovado para publicação em 2 de fevereiro de 2017. 


\begin{abstract}
This article looks at Argentine attempts to mobilize the Third World support by framing the Falklands/Malvinas War as a North-South conflict. Despite fundamental ideological divisions, the Organization of American States (OAS) and the Non-Aligned Movement offered support to Argentina, while the NATO powers - the European Economic Community (EEC) and the United States - backed Great Britain. The Falklands/Malvinas was thus a conflict where nationalist agendas linked up with global narratives of decolonization and the Global South.
\end{abstract}

KeYwords: Malvinas, Global South Atlantic, Third World, Argentina.

\title{
RESUMO
}

Este artigo analisa as tentativas argentinas de mobilizar o apoio do Terceiro Mundo enquadrando a Guerra das Malvinas como um conflito Norte-Sul. Apesar das divisões ideológicas fundamentais, a Organização dos Estados Americanos (OEA) e o Movimento Não Alinhado ofereceram apoio à Argentina, enquanto as potências da OTAN - a Comunidade Econômica Europeia (CEE) e os Estados Unidos - apoiaram a Grã-Bretanha. As Malvinas foram assim um conflito em que as agendas nacionalistas se ligaram a narrativas globais de descolonização e ao Sul Global.

PalaVras-CHAVE: Malvinas, Atlântico Sul Global, Terceiro Mundo, Argentina.

\section{RESUMEN}

Este artículo examina los intentos argentinos de movilizar el apoyo del Tercer Mundo al enmarcar la Guerra de las Malvinas como un conflicto Norte-Sur. A pesar de las divisiones ideológicas fundamentales, la Organización de Estados Americanos (OEA) y el Movimiento de Países No Alineados apoyaron a la Argentina, mientras que las potencias de la OTAN - la Comunidad Económica Europea (CEE) y los Estados Unidos - respaldaron a Gran Bretaña. Las Malvinas fueran, pues, un conflicto en el que las agendas nacionalistas se vincularan con las narrativas globales de descolonización y con el Sur global.

Palabras Clave: Malvinas, Atlántico Sur Global, Tercer Mundo, Argentina. 
$\mathrm{n}$ a letter to the heads of state of the Non-Aligned Movement in May 1982, Fidel

Castro urged them to back Argentina in the Falklands/Malvinas War. ${ }^{1}$ This was a 'colonial war' "about to reach its most painful and criminal stage", which "the imperialist powers are trying to turn into a lesson for all third world countries", he impressed upon them. ${ }^{2}$ Despite fundamental ideological divisions, the Non-Aligned Movement and the Organization of American States (OAS) offered support to Argentina, while the NATO powers - the European Economic Community (EEC) and the United States - backed Great Britain. This article looks at Argentine endeavors to mobilize Third World support by framing the Malvinas as a North-South conflict. Yet, portraying Argentina as an integral part of the wider Third World was fundamentally at odds with Argentine Cold War imperatives, as it required engagement with Cuba, which was the head of the Coordinating Bureau of the Non-Aligned Movement.

The Malvinas was thus a conflict where nationalist agendas linked up with global narratives of decolonization and the Global South. Despite this, the available historiography is as a general rule narrated from a North Atlantic perspective, focusing on Western Europe and the United States. ${ }^{3}$ The contribution of this article is thus twofold. It is intended to shed light on the conflict from the 'Global South Atlantic' framework that Joseph Slaughter has proposed. ${ }^{4}$ Second, it illuminates the often-complicated relationship of Latin American countries and elites with the Third World project.

Global history interrogates space and scale (Middell and Naumann, 2010). The crisis undoubtedly had an international dimension that transcended the boundaries of Latin America. Before the crisis, in the view of the military regimes in the Southern Cone, the South Atlantic was the last frontier in the Cold War. South Africa as well as the Southern Cone were portrayed as the last strongholds of Western Christian civilization fighting against communism and the increasingly decadent West (Child, 1985: 8). For Cuba, by contrast, the Atlantic was the link to Africa, where it financially and militarily supported the Angolan national liberation struggle. To Cubans and Nicaraguans the Atlantic was an explicit Third World space. During the Falklands/ Malvinas crisis, therefore, distinct geopolitical spaces overlapped, most notably between the North and South Atlantic, but also between the 'Red Atlantic' and a Cold War South Atlantic in a peculiar constellation of national, regional, and international trajectories. ${ }^{5}$ 
The islands that caused an international crisis are located in the South Atlantic, 300 miles east of Patagonia. In 1765 the British established a settlement at Port Egmont, which lasted only twelve years, as in 1774 Spanish troops occupied the island, prompting the British to abandon their settlement. After independence from Spain, in 1816 the government of the United Provinces of the River Plate, based in Buenos Aires, claimed the Falklands as legal successor to the Spanish colonial empire. ${ }^{6}$ In 1833 , however, Britain regained military control of the islands and over the course of a century a small number of settlers arrived. In 1946, Britain registered the Falkland Islands with the United Nations as a non-self-governing territory. However, Argentina continued to claim sovereignty and formally brought the dispute to the attention of the UN in 1965 in the context of decolonization. As a result, the General Assembly issued Resolution 2065, urging negotiations in order to find "a peaceful solution to the problem, bearing in mind the provisions and objectives of the Charter of the United Nations and of General Assembly Resolution 1514 (XV) and the interests of the population of the Falkland Islands (Malvinas)". ${ }^{7}$ When in the following years negotiations proved fruitless, the UN General Assembly resumed the case, and issued Resolution 3160, in 1973, expressing concern that both parties had failed to make any progress in solving the conflict. ${ }^{8}$ Essentially, two competing claims to the islands clash in the Falklands dispute. Argentina claims the islands as a successor to the Spanish empire and cites proximity, international treaties, and territorial integrity as reasons. Britain, by contrast, rests its claim on effective occupation, a norm of customary international law, and the right to self-determination of the Falkland Islanders (Weber, 1977).

With the advent of a new military junta in 1976 in Argentina, the conflict reached a new level of intensity. Under a 'process of national reorganization', the military regime assumed absolute power, dissolving Congress, political parties, and unions, while suspending human rights. The so-called 'dirty war' the junta waged on its population marked one of the bloodiest periods in South American history, resulting in the murder, torture, and disappearances of more than 30.000 perceived enemies of the state. Together with other military dictatorships, mostly located in the Southern Cone, the junta also established a transnational terror network, Operation Condor, that was responsible for the assassination of dissidents abroad (McSherry, 2005). Seeing itself as an anti-communist vanguard, the regime also financed anti-communist groups in the hemisphere. Argentine forces trained and funded counterinsurgency movements in Central America, most prominently the Contras in Nicaragua.

By the early 1980s, decades of unsuccessful negotiations had passed, and the Argentine regime and public were getting increasingly frustrated. In 1981, an internal power struggle within the military junta erupted, which was under immense international and 
economic pressures. General Galtieri managed to overcome his rivals thanks to the support of the Navy General Anaya. However, the price for this victory was the recovery of the Malvinas, a major political ambition of the Argentine Navy, meaning that a military solution to resolve the conflict once and for all was put on the political agenda. Thus, contrary to the popular notion that the Argentine junta used the Malvinas conflict as a tactic to divert from domestic problems, as forwarded by the likes of Hasting/Jenkins and T.V. Paul, concrete plans for the invasion had already been drafted by December $1981 .{ }^{9}$ On January 6, 1982, the junta had decided to invade should negotiations prove unsuccessful. Evidence suggests that the original date for the invasion was scheduled for July 1982, but was then pushed forward (Piñeiro, 1992: 11-16).

The international community did not take Argentine sable rattling seriously and was thus taken aback when news broke that Argentine forces had occupied the Falklands on the early morning of April 2. Argentine troops overran the small military station at Port Stanley and occupied the islands. International and United Nations reaction was to condemn the invasion. The following day, the UN Security Council issued Resolution 502 demanding an immediate withdrawal of Argentine troops and called upon both countries to seek "a diplomatic solution to their differences and to respect fully the purposes and principles of the charter of the UN". ${ }^{10}$ Equally, the European Economic Community backed Britain and imposed trade sanctions on Argentina in mid-April. ${ }^{11}$ The conflict intensified on April 5, when Great Britain decided to send a task force to the South Atlantic. This came as a surprise to the Argentine junta which had gambled on a very different British reaction, expecting it to cave in and offer diplomatic negotiations. In March 1982, Argentine Foreign Minister Costa Méndez jocularly had commented on the likelihood of a British military reaction: "London had only one plan: procrastination." 12 After the fiasco President Galtieri stated: "Personally, I judged any response from the English scarcely possible, indeed absolutely improbable." 13

The talks and offers of negotiation in the following weeks, first led by Alexander Haig, U.S. Secretary of State, and then resumed under Peruvian President Belaúnde Terry, all failed. On April 30, shortly before the actual military maneuvers started, Washington abandoned neutrality and announced its support for Britain. On May 2, a British submarine attacked the Argentine vessel General Belgrano and sank it, causing the deaths of 323 Argentine sailors. The incident marked a turning point in public perception of the war, causing many Latin American governments to side with Argentina. It would take six weeks and close to 900 casualties before the Argentine junta succumbed to the military superiority of the British forces, and surrendered unconditionally on June $15 .{ }^{14}$ The defeat of the Argentine military 
caused a profound reaction of shock and disbelief in Argentine society and eventually lead to the downfall of the military junta and democratic elections in 1983.

Argentines perceive the Falklands conflict as a long-held grievance, deeply rooted in their culture. They are raised and systematically educated in the belief that 'las Malvinas fueron, son y serán Argentinas' ('the Malvinas were, are, and will always be Argentine'). Therefore, when the military junta announced the occupation of the islands, public reaction was overwhelmingly enthusiastic. The Falklands conflict was seen in Argentina, as well as in Latin America in general, as part of the post-colonial struggle of the continent.

It was time, according to the general chorus of the Argentine press, for Britain to face reality, namely that colonialism was over. "Colonialism is dead, and Great Britain has accepted the fact, except in the case of Argentina's southern Atlantic islands" thundered La Prensa, the conservative doyen of Buenos Aires' newspapers. ${ }^{15}$ Furthermore, the Argentine junta perceived its action as a form of self-help in a world system that structurally disadvantaged Latin America. Institutions such as the UN, in which global asymmetry was inscribed in the Security Council, favored former colonial and imperial powers, which had repeatedly exploited and intervened in Latin America (Reisman, 1983: 311). True enough, with Britain a permanent member in the UN Security Council, any resolution supporting the Argentine cause would be vetoed, and as happened in early July. Jorge Lauricica summed up this predicament precisely. "Before April 2, Argentine decision makers considered that there were no conflict-limiting norms and institutions, no organizations concerned with their grievances, and no effective mediation services, and that, in general terms, there was no 'justice' available for Argentina" (Lauricica, 2000: 85). By occupying the Falklands, therefore, Argentina had taken justice into her own hands.

Some comments went even further and framed the conflict as a North-South struggle between industrialized and underdeveloped Third World countries. In the May edition of the weekly magazine El Porteño, entitled "The North against the South," the authors portrayed Argentina as a Third World country suffering from the vestiges of colonialism, "from hunger and unemployment, inflation and dictatorships, monoculture and piecework". ${ }^{16}$ Thus, Argentina attempted to shore up support by framing the conflict in anti-colonial terms, condemning Great Britain for not only violating 'Argentine territory', but also having the effrontery "to recolonize territories that belong to us". ${ }^{17}$ Even the writer Ernesto Sábato, who would become famous as the author of the prologue to the 1984 truth commission report, described the conflict as not as struggle of a democracy against a military dictatorship but "as a fight of an empire against an entire population". ${ }^{18}$ 


\section{INTER-AMERICAN RELATIONS AND THE MALVINAS}

s a rule, Latin American governments have always endorsed Argentine claims over
the islands, both in bilateral as well as multilateral relations. Indeed, at the birth of the Organization of American States (OAS), the Malvinas played a role. More specifically, the Falklands /Malvinas had been included in the hemispheric security zone stipulated in Art. 4 of the 1947 Rio Treaty. At the time, the Argentine Peronist government had successfully fought for the inclusion of the islands in the hemispheric security zone in 1947. In a 1949 report by the American Committee on Dependent Territories, the Falklands featured next to Greenland, the Guyanas, all Caribbean islands under European control, parts of Belize, as well as the American Zone of the Antarctic (González, 2013). Similarly, in OAS resolutions and communiques, Latin American governments sided with Argentina throughout the 1960s and 1970s. In January 1976, the Inter-American Juridical Committee issued a statement supporting the Argentine juridical claim, which was to become the legal foundation for future decisions within the interAmerican system.

Most Latin American governments and elites thus perceived the Falklands conflict as a colonial struggle, and followed the Argentine lead, which successfully painted the occupation of the Malvinas as a colonial conflict. However, many also viewed the recourse to military force in a critical light, arguing that it contravened a long-standing tradition of peaceful settlement of conflicts in inter-American relations and felt that it threatened to destabilize a region with many territorial disputes.

Nevertheless, several events rubbed Latin American governments the wrong way and ultimately pushed them to, at least officially, declare support for Argentina. Resolution 502's swift passing by Security Council was considered such a clear British diplomatic victory that it confirmed Latin American suspicions of the Security Council as an organization by and for the Global North. However, the ultimate turning point was the sinking of the Argentine vessel Belgrano and the subsequent death of 323 sailors. This, together with the open alignment of the United States with the United Kingdom and the provision of logistical and intelligence support by US forces, further radicalized many Latin American governments.

Stressing the legitimacy of Argentine actions in an OAS debate, the Venezuelan Foreign Minister Zambrano highlighted that "Argentina's claim is backed by all the juridical reasons that strengthen its position in the field of law, while the British presence in the Malvinas is nothing more but a relic of the era of expansion of the British Empire". ${ }^{19} \mathrm{He}$ also added, "[l] $\mathrm{t}$ is the same fleet that in 1833 demolished Latin American rights over the Malvinas islands [...] The same that maintained the Opium War, that colonized the Caribbean and backed all of 
the aggressions and destructions that were committed by England against Latin America, Asia and Africa". Zambrano's view was not unique, as similar ideas were echoed up and down the subcontinent in the press and public speeches.

Above all, the EEC sanctions against Argentina imposed on April 10 touched a sore spot in Latin America: its economic dependence and vulnerability. The sanctions infuriated Latin American governments in what they perceived as an asymmetric struggle between underdeveloped dependent countries and developed former colonial powers. This struggle was equally framed in the language of decolonization, charging that the 'the ancient colonial powers' had generated "structures of political dependence, economic and military, adulterating international cooperation by instrumentalizing weak peoples". ${ }^{20}$ The sanctions were only possible, the Argentine OAS delegate argued, because the European Economic Community, with Britain at the forefront, was able to "take advantage of its dominant role in the global economy". ${ }^{21}$ The Argentine Foreign Minister picked up this theme, portraying the Malvinas conflict as a struggle "between the Latin world and an Anglo-Saxon alliance of the industrial Northern Hemisphere". 22

The OAS thus explicitly condemned the sanctions as illegal actions in its resolution in late April in what in other terms was a rather measured document. ${ }^{23}$ In early June, the Latin American and Caribbean Economic System (SELA), an organization founded in 1975 to promote economic cooperation and social development between Latin American countries, warned that "coercive economic measures against a member state by a powerful group of industrialized countries is a very grave act that threatens its sovereignty and the economic security of the member states. ${ }^{24}$ This is not to say that Latin American governments endorsed Argentine military actions, as many were very critical of it, but they by and large agreed with the Argentine framing of the Malvinas as a postcolonial conflict.

\section{The FALKLANDS/MALVINAS AS A THIRD WORLD STRUGgLE}

\section{A longside Latin American solidarity, the Argentine junta attempted to rally Third World countries behind it. Whereas the perception of Latin America as part of the Third World} had been readily accepted in some parts of Latin America, this was not true for Argentina. Argentine national narratives centered on an alleged 'white' Argentina, closely tied to Europe in both culture and descent. Under the military regime, this notion was reinforced by projecting the image of Argentina as the defender of Western Christian civilization, caught up in a struggle against communism. Before the outbreak of the conflict, Argentine and Brazilian military officers had cast the struggle of the Falklands as the seizure of a logistically indispensable base 
for the defense of Christendom in Southern Africa and America, against godless forces aided by Cuba or represented by NATO. ${ }^{25}$ As the South African Vice Admiral James Johnson remarked in 1976: "The Communists are turning the area into a Soviet lake" (Hurrell, 181). The Argentine regime accordingly renewed efforts to establish a South Atlantic security organization, a project that dated back to 1949, when Argentina and Brazil had floated the idea of SATO. In 1967, Argentina and South Africa relaunched the initiative through a series of information and intelligence exchanges. In 1981 the Argentines hosted a meeting in Buenos Aires to discuss the possible formation of a South Atlantic pact, but the elusive SATO failed to materialize. The junta's preoccupation was not unique. Geopolitics, paired with the supreme doctrine of national security, featured prominently in all the military dictatorships in the Southern Cone in the 1960s and 1970s. In Argentina, as in Brazil, Chile, and Peru, geopolitical visions that identified their maritime space in the Atlantic or the Pacific as a 'natural' extension of their national territory were rampant. Moreover, all shared territorial ambitions that went beyond their borders (Child, 1985).

As recently as January 1982, Foreign Minister Costa Méndez had proclaimed that Argentina did not belong to the Third World, proclaiming that Argentines were "white and Christian". ${ }^{26}$ However, when support failed to materialize, the Argentine regime realized that it could more easily summon support from Third World countries, many of them neither white nor Christian, by presenting the conflict within a colonial framework. This led to the somewhat paradoxical situation, in which the non-aligned governments of Cuba and Nicaragua supported the Argentina case, and Argentina found "itself a first-class ally of countries it had fought nationally and internationally, in political terms". ${ }^{27}$

While the Argentine junta ruthlessly persecuted leftist or any other kind of opposition at home, its sponsored terror abroad, and Central America had been specifically targeted. Since the 1979 Sandinista revolution, a socialist revolutionary government had ruled in Nicaragua whose ideology was diametrically opposed to the national security doctrine of the Argentine junta. Fearing a 'second Cuba', the Reagan government had instructed the CIA to finance the Contras, right-wing contra-revolutionaries, to overthrow the Sandinista government. Seeing itself as an anti-communist vanguard in the hemisphere, the Argentine military, working with US forces, were heavily involved in training and equipping the Contras, although it is not clear if the Sandinistas were aware of this at this point (Armony, 1997). Yet in the bizarre circumstances of 1982, shared opposition to the United States made both governments natural allies, corresponding to the principle of 'my enemy's enemy is my friend'.

Moreover, since 1973 Argentina had also been a member of the Non-Aligned Movement, in which Cuba featured prominently. Even after the 1976 coup, the junta decided 
not to revoke membership and one of the reasons for this was to stay within a political alliance sympathetic to its Falklands campaign. As the military dictatorship soon came heavily under attack internationally because of its human rights violations, and with the Carter administration cutting funding and military support, the regime opted to stay in the Non-Aligned Movement, where it hoped to find allies not just for the Malvinas/Falklands issue, but also for its quest for nuclear development.

Since 1975, the Argentine junta had been successful in including the issue in every final statement of Non-Aligned conferences. Even though African countries resented Argentine participation because of its diplomatic relations with racist countries, notably South Africa, they did not rescind Argentine membership. The Argentine Foreign Minister Oscar Antonio Montes even participated in the Non-Aligned Meeting of Foreign Ministers in Belgrade, in 1978, where he hoped to find a sympathetic forum to counter the international campaign against the human rights abuses of the military regime. The Argentine regime volunteered Buenos Aires as the location for the First Regular Meeting of the Non-Aligned Coordinating Countries on the Peaceful Uses of Nuclear Energy held in June and July 1980. As host country, Argentina took the lead in arguing for the right to technology and criticized the non-proliferation policy that had been enforced by the developed countries in the so-called 'London Club'. This discriminatory practice, as the head of the national nuclear energy commission (CNEA), Vice-Admiral Carlos Castro Madero, argued, had resulted in a two-tier system in which some countries had access to nuclear technology, but others were denied this. Argentina wanted to break this technological dependency and, crucially, also wanted to draw level with its neighbor and rival Brazil which had successfully built several nuclear power plants with the help of the Federal Republic of Germany. ${ }^{28}$

Argentine participation in the Non-Aligned Movement caused constant friction between the linea dura and the soft-liners or advocates of the linea blanda within the Argentine regime, especially after the 1981 Non-Aligned Conference in New Delhi. This power struggle within the Argentine military junta came to a head in 1981. The press, representing the views of the hawks, charged the Argentine delegation with courting those who had financed and trained the Montoneros and the Ejército Revolucionario del Pueblo, Argentine guerrilla groups. Since Cuba featured prominently in it, the hard-core anti-communist section in the military found the Non-Aligned especially unpalatable.

In January 1982, the Argentine Foreign Ministry created an ad-hoc commission to decide whether Argentina should continue as a member of the Non-Aligned Movement. In a report, the military attaché in Washington D.C., Gil, recommended downgrading from official membership to observer status (Cisneros/Escude 1998: 289). Yet, this change in status never materialized because of the outbreak of the war and the support of the non-aligned bloc. 
Furthermore, Argentina also had excellent economic relations with the Soviet Union, as one of its major grain suppliers. In selling its produce, Argentina had been defying the trade embargo imposed by the United States because of the Soviet invasion of Afghanistan. This measure had been directed at the Carter administration, which had heavily criticized human rights violations in Argentina, cut aid and funding, and blocked loans by international finance institutions. More generally, it reflected Argentine attempts to adopt a more independent foreign policy, but also underlined the fact that, when push came to shove, Latin American foreign policies were very pragmatic. As General Videla, head of the Junta, declared in 1981, the relationship with the Soviet Union was "no more than a pragmatic relationship in the economic field" with no political implications. ${ }^{29}$

The relationship between Havana and Buenos Aires had been notoriously contentious in the previous decades, both countries having severed diplomatic ties with each other in 1962. Argentina had supported Cuban ostracism and voted for the economic embargo in 1964 in the Organization of American States. While there had been a short-lived détente under Perón in 1973 when trade relations were established, the military coup had put an end to this nascent relationship. However, when economic relations were resumed with Cuba in 1979 Castro invited Argentina to attend the 1979 Non-Aligned Conference in Havana as a gesture of goodwill. General Videla declined, but he nonetheless sent a delegation headed by the sub-secretary of the Foreign Ministry Carlos Cavándoli to head off the increasing political isolation of the Argentine Junta. However, although there were some economic links in 1982, Argentina had no diplomatic relations with Cuba.

Cuba's ostracism in the hemisphere only strengthened its fervor to spread revolution internationally. Cuba as a founding member of the Non-Aligned Movement had slowly emerged as one of the leaders of the Global South. ${ }^{30}$ In 1966, Castro hosted the Tricontinental Conference to promote Third World solidarity and a more radical policy of supporting anticolonial resistance in Africa, Asia, and Latin America (Prashad, 2007). During the 1970s, Cuba further pursued an international Third World agenda, lending support - financial, military, and otherwise - to national liberation struggles in Africa. As Piero Gleijeses has pointed out, Cuba was one of the few Third World countries that intervened internationally, most actively in Angola, Mozambique and Ethiopia (Gleijeses, 2002). Within the hemisphere, however Cuba had moved away from its previous goal of spreading revolution and this softening had made it more palatable for Latin American governments to resume diplomatic relations.

Since the early 1970s, Cuban isolation in Latin America had waned somewhat. In the OAS, British Caribbean countries such as Jamaica and Trinidad and Tobago, then under leftist governments, had signaled that they would only join if there were not to be bound to the 
resolutions regarding Cuba. During the $16^{\text {th }}$ OAS Meeting of Foreign Ministers in San José, Costa Rica, the "Freedom of Action Resolution" was passed. The resolution allowed memberstates to resume relations with Cuba, effectively declaring previous OAS resolutions on Cuba as void (Dominguez, 1989: 225-240).

After the demise of the first generation of non-aligned leaders in the mid-1960s, Cuba rose to prominence within the movement during the 1970s. In 1979, Fidel Castro took over as Secretary General of the movement and as a result the Coordinating Bureau was relocated to Havana. However, Cuba was increasingly isolated in the movement, when it decided to openly support the Soviet invasion of Afghanistan later that year. As a result, the 1981 Non-Aligned Conference, originally scheduled in Havana, was relocated to New Delhi in protest. Whereas relations with Latin America were slowly improving, relations with the non-aligned countries had deteriorated, leaving Cuba in an ever-precarious economic and international position.

Latin American countries did not join the Non-Aligned Movement in droves in the 1960s. Although by the late 1970s Latin American participation had risen, most were official observers and, even if they were formal members they never assumed a dominant role. ${ }^{31}$ The majority of new members actually came from within the British Caribbean subgroup, as many of the smaller Latin American countries had neither the capacity nor the resources, and, as some would argue, the inclination to engage meaningfully with the Global South.

However, at the end of the 1970s, changes were afoot in Latin America. In 1979, the Sandinistas had taken power in Nicaragua in the second revolution in Latin America after the Cuban in 1959. Cuba had supported their fight and those of other guerrilla movements in El Salvador and Guatemala, as well as aiding the socialist Maurice Bishop in Grenada. Nicaragua and Grenada had also joined the ranks of the Non-Aligned Movement and had attended the 1979 Non-Aligned Summit in Havana, where Cuba had portrayed them as the new vanguard of revolutionary movements in the hemisphere.

Interestingly, this meant that both Cuba and Argentina, despite widely diverging political interests, not only had close relations with the USSR, but also found themselves politically isolated. From the beginning of the crisis, Cuba offered support, both rhetorical and to a lesser extent material, to the Argentine regime. Even though the Castro regime had backed the Argentine claim to the islands as a rule, Castro understandably had little sympathy for the authoritarian regime. However, the Cuban government saw it as an opportunity to drive a wedge between the United States and Latin America, to break hemispheric isolation, and possibly to curry some favor with the Soviets. Yet, the Cuban government was also driven by another political agenda: territorial decolonization. The Cubans held hopes that a successful Argentine negotiation would provide them with more leverage over the question 
of Guantánamo, which they argued was a similar case of an unlawfully occupied territory that should be restituted to Cuba. In a private conversation with a Canadian official during a Commonwealth celebration, Castro shared his dislike for the Argentine junta. Describing the crisis as "a plague on both their houses", he concluded "that the best outcome for Cuba might be if the British and Argentine governments succeed in destroying each other" ${ }^{32}$

Shortly after the occupation of the islands, on April 5, the official mouthpiece of the Cuban regime, the newspaper Granma, published an editorial note, in which Cuba and the non-aligned countries "manifested support for Argentina". ${ }^{33}$ During a meeting with British ambassador David Churchill Thomas, Vice-President Rodríguez and Deputy Foreign Minister Viera laid down the Cuban view. They reiterated that Cuba had always endorsed Argentine sovereignty over the islands. Rodriguez pointedly remarked that it was not the Cubans' fault that "British procrastination in negotiating a peaceful solution had obliged Argentina to assert its claim by force". He also warned Thomas that military actions would provoke a backlash as "[H]owever much NAM members might disapprove of the Argentine action, they would be bound to come out against the use of force by a major ex-colonial power against a Third World country". ${ }^{34}$

Yet, Cuban support was not just lip service. The Brazilian military were taken aback, when, completely unannounced, a Cuban plane entered Brazilian airspace on April 9. Perplexed, the Brazilians noted that on board was the Cuban ambassador, carrying a personal message from Fidel Castro to the Argentine junta. In the name of the government of Angola, it offered Angolan airbases as stopovers for an airlift between Libya and Argentina. ${ }^{35} \mathrm{And}$ rumors abounded throughout the crisis that Cuba and the Soviet Union were shipping weapons to Argentina. ${ }^{36}$

Thus, shortly after the outbreak of the Malvinas conflict, the Cuban ambassador swiftly returned to Buenos Aires to resume diplomatic exchanges on April 10, bringing with him other staff members of the Coordinating Bureau of the Non-Aligned Movement. ${ }^{37}$ As the situation in the South Atlantic became increasingly tense, the Argentine junta seized the opportunity to call for Third World solidarity and support from non-aligned countries. This answer came promptly, as on April 23, the Bureau issued a declaration openly supporting Argentina's claim to the Malvinas as a "just claim. " 38

After the Reagan administration announced it would back the United Kingdom in the military confrontation on April 30, Cuban rhetoric grew more aggressive, as it seized the opportunity to rage against both British and Yankee imperialism. On May 1, the Cuban government issued a second statement chiding the UK for 'intolerable aggression' and labelling the United States as the 'enemy of Latin American and Caribbean peoples'. Calling 
for Latin American solidarity, it argued that the Argentine struggle was 'our cause'. Even Mario Firmenich, the exiled leader of the Montoneros, an Argentine guerrilla group that had been hunted down by the junta, expressed his support for the Argentine move. ${ }^{39}$ In an interview, Firmenich told the news agency Reuters that he was engaged in promoting non-aligned support for Argentina in Cuba.

On May 5, the Cuban Vice President Carlos Rafael Rodríguez proclaimed that Cuba was prepared to aid Argentina through all means, even military, in an interview with the French newspaper Le Monde. ${ }^{40}$ While qualifying that Cuba's support "was for the Argentine people, not the junta", Rodríguez replied that this was not a military act because "the islands were Argentina's own territory and the islanders had no rights since they were not the original inhabitants". ${ }^{41}$ In an official letter to non-aligned leaders on dated May 10, Fidel Castro was much more explicit. Depicting the conflict as a colonial war, he called on non-aligned leaders to take "whatever measures you consider appropriate to delay the imminent Anglo-American aggression against the Argentine people". Cuba thus assumed a central function in rallying support for Argentina in the Non-Aligned Movement.

At the beginning of May, with military confrontation under way and Latin American support wavering, an Argentine diplomat briefed the delegates on the first month of the war, as part of what was the first official visit of an Argentine diplomat to Cuba in more than twenty years. At the end of May, with Argentina in a dire military position, Argentine Foreign Minister Costa Méndez himself travelled to attend the Ministerial Meeting of the Coordinating Bureau of the Non-Aligned Countries that took place between May 31 and June 5. There, in a lengthy speech in which he attempted to rally the non-aligned states, Costa Méndez highlighted the liberation struggles in Algeria and Vietnam. The fight against colonialism, he declared, had been a legitimate reaction of the peoples against a system of international relations that was not only 'unjust' but also solely "benefitted colonial and imperial powers". ${ }^{42}$ However, when he referred to the continued fight of South African peoples against Apartheid, he was "greeted with laughter by some African representatives who recalled that Argentina had never previously supported their efforts against South Africa" ${ }^{43}$ To the contrary, as reported earlier, the Argentine junta had sought to strengthen political and military cooperation with South Africa and, as late as 1981, had pushed for the creation of a South Atlantic defense organization. Soon, however, the rumor circulated that Argentina was disposed to break relations with South Africa to secure non-aligned support. Desperate times called for desperate measures.

Reservations notwithstanding, another event eventually turned the tide. On June 2, the United States and Britain vetoed a UN Security Council resolution introduced by Spain and Panama that called for an immediate ceasefire. With Argentine defeat imminent, the Thatcher 
government had little interest in what they perceived as giving in. They wanted military victory. This show of force affirmed Third World suspicions that there was one justice for the superpowers and another for the 'rest'. Ultimately, it so profoundly angered Latin American governments that it strengthened their resolve to find a pro-Argentine solution in the NonAligned Conference.

As was non-aligned custom, the regional group affected directly prepared the draft. In this case, the Latin American caucus within the Non-Aligned Movement included Argentina, Peru, Bolivia, Nicaragua, and Panama, as well as the British Caribbean members of Guyana, Grenada, Jamaica, and Trinidad and Tobago. Similar to what had happened in the OAS, Latin and British Caribbean members had clashed bitterly. After three days of discussion the Latin group had worn out their English-speaking counterparts and the result was a resolution that acknowledged "that the Malvinas, South Georgias and South Sandwich Islands were an integral part of the Latin-American region", also stating "that the military actions of the United Kingdom and covert actions and pressures of other developed countries harmed the entire region". ${ }^{44}$ In a subsequent report, British diplomats complained that they had been met with "complete non-cooperation" as Cuban organizers had effectively barred any nonmembers from getting in touch with delegations. 45 In the end, it was the Latin American effort that enabled this Argentine victory, as many non-aligned members remained critical of the Argentine junta. Yet, this critical stance had more to do with the nature of the Argentine regime, its recent policies, and the fact that it had used military force to achieve its objectives, than with the question of whether the Malvinas/Falklands should be considered Argentine.

\section{Conclusion}

$\mathrm{T}$ he end of the war did not signify the end of the conflict, which continues to this day. Indeed, during a session of the UN Special Committee on Decolonization in October 2015, the Paraguayan delegate, speaking on behalf of Mercosur, expressed his disappointment that on the fiftieth anniversary of General Assembly Resolution 2065 (XX), in which the Assembly had recognized the issue of the Malvinas as one centred on sovereignty, the conflict had still not been resolved. ${ }^{46}$

The Falklands/Malvinas conflict raised questions of territoriality and sovereignty, issues that many countries in the Global South continue to grapple with. However disingenuous and self-serving the Argentine regime might have been, it showed that certain historical narratives about colonialism resonated and transcended political chasms, because they were related to similar territorial struggles all over the world. Yet, in the end, non-aligned support was 
piecemeal, because many non-aligned countries profoundly disliked the Argentine junta and had not forgotten their aggressive anti-Communist policies.

For Cuba, its involvement in the crisis resulted in the breaking of the hemispheric isolation that had commenced in 1975. In 1983 Argentina resumed diplomatic relations with the island, followed in 1986 by Brazil. By the late 1980s, the majority of Latin American states had resumed relationships with Cuba. ${ }^{47}$ As the British bitterly complained, "Cuba has cynically exploited the Falklands conflict in an effort to normalize relations with Latin America". ${ }^{48}$ In so doing, it had overcome seemingly impossible ideological divisions.

\section{Notes}

1 I use the term Malvinas and Falklands interchangeably.

2 National Archives Kew (NA hereafter), FCO 99/1108 Cuba-Falkland Crisis-International Organisations, Telegram, 14 May 1982.

3 See, for example, Freedman (2007), Hastings and Jenkins (1983), Danchev (ed.) (1992), Paul (1994). The notable exceptions to this are González (2013) and Freedman and Gamba-Stonehouse (1991). Notable Argentine works include Piñeiro (1992) and Cardoso and Kirschbaum (1984).

4 Joseph R. Slaughter and Kerry Brystrom, Introduction, "The Sea of International Politics: Fluidity, Solvency, and Drift in the Global South Atlantic," not yet published. I want to thank Joseph Slaughter for sharing this with me.

5 For an overview on different spatial conceptions of the Atlantic, see Slaughter/Brystrom.

6 This principle of uti possidetis juris stipulates that when colonies become states, territories and boundaries transfer from the coloniser to the former colony. This norm of international law was coined and shaped in Latin American international law. See Beck (1988).

7 UN Resolutions Adopted by the General Assembly during its Twentieth Session.

8 See Laucirica (2000).

9 See also Cardoso/Kirschbaum (1984: 46).

10 UN Security Council Resolution 502, dated April 3, 1982, was a major accomplishment for the British Foreign Office, as it gave Britain the right to act in self-defence and to claim self-determination for the Falkland Islanders (Lauricica, 2000: 89).

11 The sanctions were decided on against the reservations of Italy and Ireland.

12 As quoted in Danchev (1992: 3).

13 As quoted in David Rock (1997: 377).

14 Overall, 255 British and 641 Argentine soldiers either died or were reported as missing. Informe Rattenbach. El Drama de las Malvinas. Buenos Aires: Espartaco, 1988. 
15 La Prensa, 2April 1982.

16 El Porteño, "The North against the South", May 1982.

17 Statement by the Argentine delegate Rául Quijano. Acta de la primera sesión de la comisión general, 26 April 1982, OEA/Ser.F/ll.20 Doc.20/82.

18 El Clarín, Opina Sábato, 18 April 1982.

19 El Día, Los cancilleres de AL pasaron encendida revista a los antecedentes colonials ingleses, 27 April 1982.

20 Statement by the delegate of Venezuela, Zambrano. Acta de la primera sesión de la comisión general, 26 April 1982, OEA/Ser.F/ll.20 Doc.20/82.

21 Statement by the Argentine delegate. Acta de la primera sesión de la comisión general, 26 April 1982, OEA/Ser.F/II.20 Doc.20/82.

22 The Washington Post, "O.A.S. Demands End to Aid for Britain", 29 May 1982.

23 Serious Situation in the South Atlantic - Resolution adopted on 28 April 1982. OEA/Ser.F/l..20 Doc.28/82 rev.328 April 1982.

24 Note from the Special Delegate of the Argentine Republic transcribing the text of a decision adopted by the meeting of high-level government experts of the Latin American Economic System (SELA) OEA/Ser.F/II.20 Doc.89/82, 7 June 1982.

25 Conversation with Charles Jones, recalling his discussions with senior Brazilian officers at the 1995 Brazilian strategic studies conference, in Rio de Janeiro.

26Der Malwinen/ Falkland Konflikt im Spiegel der lateinamerikanischen Presse. Hamburg: Institut für Iberoamerikakunde, 1984, x.

27 Uno más Uno, "Insólitas alianzas", 3 May 1982.

28 This is report in detail in Cisneros/Escude (1998, vol. XIV, cap. 68).

29 As quoted in Russell (1984: 178).

30 For an, albeit short and somewhat outdated, overview of Cuba's relationship with the Non-Aligned Movement, see Levi (1979).

31 In 1979, Argentina, Bolivia, Belize, Cuba, Grenada, Guyana, Jamaica, Nicaragua, Panama, Peru, and Trinidad and Tobago formed part of the Latin American caucus in the Non-Aligned Movement.

32 NA, FCO 99/1096 Cuba/UK Political Relations, Telegram 19 April 1982.

33 Brazilian National Archives (AN hereafter). Serviço Nacional de Informações, SNI Sumário Diário de Informações No.2 E2.1 EME, 5 April 1982.

34 NA, FCO 99/1107 Cuba Falkland Crisis-UK. Telegram from Havana, 22 April 1982.

35 AN, Ministerio do Exército. Sumário Diário de Informações No.41-E 2.1. June 4, 1982.

36 NA, FCO 99/1106 Secret, Telegram 7 May 1982.

37 El Clarín, "El gobierno cubano repuso su embajador en Buenos Aires," 10 April 1982. 
38 El Clarín, "Apoyo de los No Alienados," 23 April 1982.

39 AN, Ministerio do Exército, Sumário Diário do Informações No. 5-E.1.2, 12 April 1982.

40 National Security Archive, Telegram, Secretary of State, 7 May 1982.

41 NA, FCO 99/1106 Secret, Telegram 5 May 1982. NA, FCO 99/1106 Secret, Telegram 7 May 1982.

42 La Prensa, Discurso del canciller Costa Méndez ante la Reunión del Movimiento de Países No Alineados en La Habana, 4 June 1982.

43 NA, FCO 99/1108 Cuba-Falkland Crisis-International Organisations, Telegram 4 June 1982.

44 NA, FCO 99/1104 Cuba: Foreign Policy, Telegram 11 June 1982.

45 NA, FCO 99/1104 Cuba: Foreign Policy, Telegram 11 June 1982.

46 UN Meetings Coverage, "Argentina Enjoys Widespread Support over Question of Falklands (Malvinas) as Fourth Committee Begins Debate on Decolonization Matters," GA/SPD/580, 8 October 2015.

47 By 1985, only Chile, El Salvador, Paraguay, and Honduras had not resumed relations with Cuba.

48 NA, FCO 99/1108 Cuba-Falkland Crisis-International Organisations, Report on NATO Political Committee, 10 August 1982.

\section{SOURCES}

Der Malwinen/ Falkland Konflikt im Spiegel der lateinamerikanischen Presse. Hamburg: Institut für Iberoamerikakunde, 1984.

Informe Rattenbach. El Drama de las Malvinas. Buenos Aires: Espartaco, 1988.

British National Archives Kew, Foreign and Commonwealth Office Documents (FCO).

Brazilian National Archive.

Columbus Memorial Library of the Organization of American States. OEA/Ser.F/ll.20 Doc.20/82.

National Security Archive, Washington D.C.

UN Meetings Coverage.

\section{NEWSPAPERS}

La Prensa (Argentina)

El Porteño (Argentina)

El Clarín(Argentina)

El Día(Argentina)

Uno más Uno (Mexico)

The Washington Post (USA) 


\section{BIBLIOGRAPHY}

ARMONY, Ariel. Argentina, the United States, and the anti-communist crusade in Central America, 1977-1984. Athens, OH: Ohio University Centre of International Studies, 1997.

CARDOSO, O. and KIRSCHBAUM, R. Malvinas: la trama secreta. Buenos Aires: Sudamericana, 1984.

CHILD, Jack. Geopolitics and conflict in South America: quarrels among neighbors. New York: Praeger, 1985.

CISNEROS, Andrés y ESCUDE, Carlos. Historia general de las relaciones exteriores de la República Argentina. Buenos Aires: Centro de Estudios de Política Exterior, 1998.

DANCHEV, Alex (ed). International perspectives on the Falklands Conflict. Basingstoke: Macmillan, 1992.

DODDS, Klaus. Pink ice: Britain and the South Atlantic Empire. London: Tauris, 2002.

DOMINGUEZ, Jorge I. To make a world Safe for Revolution: Cuba's Foreign Policy. Cambridge, MA: Harvard University Press, 1989.

FREEDMAN, Lawrence. The official History of the Falklands Campaign. London: Routledge, 2007.

— \& GAMBA-STONEHOUSE, Virginia. Signals of war: the Falklands Conflict of 1982. London: Faber and Faber, 1991.

GLEIJESES, Piero. Conflicting missions: Havana, Washington, and Africa, 1959-1976. Chapel Hill, NC: University of North Carolina Press, 2002.

GONZÁLEZ, Martín Abel. The genesis of the Falklands (Malvinas) Conflict: Argentina, Britain and the failed negotiations of the 1960s. Basingstoke: Palgrave Macmillan, 2013.

HASTINGS, Max \& JENKINS, Simons. The battle for the Falklands. London: M. Joseph, 1983.

HURRELL, Andrew. The Pplitics of South Atlantic security: a survey of proposals for a South Atlantic Treaty Organization. International Affairs, vol.59, no. 2 (Spring 1983).

LAURICICA, Jorge. Lessons from failure: the Falklands/Malvinas Conflict. Seton Hall Journal of Diplomacy and International Relations (Summer/Fall 2000).

LEVI, Rozita. Cuba and the Non-Aligned Movement. In: Blasier, Cole and Mesa-Lago, Carmela (ed.). Cuba in the world. Pittsburgh, PA: University of Pittsburgh Press, 1979.

MCSHERRY, J. Patrice. Predatory States: Operation Condor and Covert War in Latin America. Lanham, MD: Rowman and Littlefield, 2005.

MIDDELL, Matthias \& NAUMANN, Katja. Global History and the spatial turn: from the impact of area studies to the study of critical junctures of globalization. Journal of Global History, vol.5, 2010.

PAUL, T.V. Asymmetric conflicts: war initiation by weaker powers. Cambridge: Cambridge University Press, 1994.

PRASHAD, Vijay. The darker nations: a people's History of the Third World. New York: New Press, 2007.

PIÑEIRO, Armando Alonso. Historia de la Guerra de Malvinas. Buenos Aires: Planeta, 1992.

REISMAN, Michael. The struggle for the Falklands. The Yale Law Journal, vol. 93, no. 2, December 1983. 
STELLA PARESA KREPP

ROCK, David. Argentina, 1516-1987: from Spanish colonization to Alfonsín. Berkeley, CA: University of California Press, 1997.

RUSELL, Robert. Argentina y la política exterior del regimen autoritario (1976-1983): una evaluación preliminar, Estudios Internacionales, vol. 17, no. 66, 1984.

WEBER, Hermann. "Falkland Islands" oder "Ma/vinas"? Der Status der Falklandinseln im Streit zwischen Grossbritannien und Argentinien: eine völkerrechtliche Fallstudie. Frankfurt am Main: Metzner, 1977. 